\title{
Three influencing factors on the level of non-ionizing radiation
}

\author{
Vasil Bilero
}

Department of Physics, Faculty of Natural Sciences, University of Gjirokaster, Gjirokaster, Albania; vasilbilero@yahoo.com

Received 22 May 2010; revised 25 June 2010, accepted 28 June 2010.

\begin{abstract}
The role of three factors on the level of nonionizing radiation is treated in this project: that of 1) the distance of the exposed body from the source, 2) the power of the source device and 3) the frequency of the source. The important factor of time, as well as other factors, are not at all ignored in this manuscript. In this work I emphasise the rules of the relationship with this necessary contaminant, and that exposures towards it should be avoided as far as possible.
\end{abstract}

Keywords: Source; Radiation; Non-Lonizing; Distance; Power; Frequency; Exposure

\section{INTRODUCTION}

The general public is becoming increasingly aware of the exposure that they face towards electromagnetic fields. Rapid development in science has produce technologies which the public has become dependant on. For the most part, public knowledge is insufficient to fully understand the effects of these technologies and their potential hazards. Even professionals of different fields, in state or private enterprises, often lack the sufficient scientific knowledge to appropriately contain exposures to electromagnetic fields and frequently have a negative influence on their containment. For these reasons, it is the physicist's urgent duty to raise public awareness of this issue by whichever means he is able, and also to guide governmental organs in how, and to what extent, legislation should restrict this necessary contaminant.

\section{THE WAVE NATURE OF ELECTROMAGNETIC RADIATION}

It is known that radiation has a wave nature. Thus non-ionizing radiation as a consisting part, has the same wave nature. The energy of non-ionizing radiation is small and it can't achieve ionization of material, including here the biological molecule. However it does in- crease its thermal energy, and this is an irreversible process for the living beings [1-7].

\section{SOURCE CLASSIFICATION OF NON-IONIZING RADIATION}

Here two classifications are presented in order to create an idea of the sources of non-ionizing radiation:

a) The classification according to the effects see $[8,9,12]$.

b) The classification according to the frequencies see [13].

\section{SOME PHYSICS SCALES ACCORDING TO WHICH THE NON-IONIZING RADIATION IS MEASURED.}

The non-ionizing radiation is measured according to some main physics scales: contact current $\left(\mathrm{I}^{c}\right)$, current density $(\mathrm{J})$, magnetic field strength $(\mathrm{H})$, magnetic flux density (B), electric field strength (E), power density (S) and specific energy absorption rate (SAR, SAR ${ }^{m}$ ) $[10,11]$.

\section{MEASUREMENTS OF NON-IONIZING RADIATION}

The measurements have been taken in the districts of Gjirokaster and Delvinë, Albania.

1) The object of measurements:

a) The non-ionizing radiation relation to the source distance - exposed object (See Figure 1, Figure 2 and Figure 3).

b) The non-ionizing radiation dependence on the power of source device ( See Figure 4 and Figure 5).

c) The non-ionizing radiation dependence on the frequency of source (See Figure 6 and Figure 7).

2) Measurements: Figure1, Figure 2, Figure 3, Figure 4, Figure 5, Figure 6, Figure 7

3) Comments on measurements:

a) Measurements of the magnetic induction of some 


\begin{tabular}{|c|c|c|c|c|c|c|c|}
\hline \multirow{2}{*}{$\begin{array}{c}\text { No. } \\
1\end{array}$} & \multirow{2}{*}{$\begin{array}{c}\text { Object measured } \\
\text { Under the } 110 \mathrm{kV} \text { aerial } \\
\text { line in } \mathrm{H} / \mathrm{C} \text { Bistricë }\end{array}$} & \multicolumn{5}{|c|}{$\begin{array}{l}\text { The level of magnetic induction in } \mathrm{B}(\text { in } \mu \mathrm{T}) \text { in dependence of distance } \\
\text { (the average value of } 6 \text { measurements for every measure point). }\end{array}$} & \multirow{2}{*}{$\begin{array}{c}\begin{array}{c}\text { Europe norm. } \\
\text { of exposure in } \\
\mathrm{B}(\mu \mathrm{T})\end{array} \\
\mathbf{0 . 5}\end{array}$} \\
\hline & & $\begin{array}{l}25 \mathrm{~m} \\
0.545\end{array}$ & $\begin{array}{c}26.5 \mathrm{~m} \\
0.541\end{array}$ & $\begin{array}{l}28 \mathrm{~m} \\
0.511\end{array}$ & $\begin{array}{l}29 \mathrm{~m} \\
0.490\end{array}$ & $\begin{array}{l}30 \mathrm{~m} \\
0.464\end{array}$ & \\
\hline 2 & $\begin{array}{l}\text { Under the } 10 \mathrm{kV} \text { aerial } \\
\text { line of shoe factory in } \\
\text { Gjirokaster }\end{array}$ & $\begin{array}{c}4 \mathrm{~m} \\
0.482\end{array}$ & $\begin{array}{c}5 \mathrm{~m} \\
0.413\end{array}$ & $\begin{array}{c}6 \mathrm{~m} \\
0.398\end{array}$ & $\begin{array}{c}7 \mathrm{~m} \\
0.355\end{array}$ & $\begin{array}{c}8 \mathrm{~m} \\
0.332\end{array}$ & 0.5 \\
\hline 3 & $\begin{array}{l}\text { Under the } 6 \mathrm{kV} \text { aerial } \\
\text { line in } \mathrm{H} / \mathrm{C} \text { Bistricë }\end{array}$ & $\begin{array}{c}4 \mathrm{~m} \\
0.455\end{array}$ & $\begin{array}{c}5 \mathrm{~m} \\
0.385\end{array}$ & $\begin{array}{c}6 \mathrm{~m} \\
0.365\end{array}$ & $\begin{array}{c}7 \mathrm{~m} \\
0.321\end{array}$ & $\begin{array}{c}8 \mathrm{~m} \\
0.312\end{array}$ & 0.5 \\
\hline 4 & $\begin{array}{l}\text { Referring point the gate } \\
\text { the electric substation, } \\
\text { Delvinë }\end{array}$ & $\begin{array}{l}\text { “-4m” } \\
0.482\end{array}$ & $\begin{array}{l}\text { “-3 m” } \\
0.421\end{array}$ & $\begin{array}{l}\text { “-2 m” } \\
0.342\end{array}$ & “-1m" & $\begin{array}{l}+1 \mathrm{~m} \\
0.211\end{array}$ & 0.5 \\
\hline 5 & $\begin{array}{l}\text { The10kV- 220V Trans- } \\
\text { former in Pall.7 in } \\
\text { Pllakë Q., Gjirokastër }\end{array}$ & $\begin{array}{c}1 \mathrm{~m} \\
1.8333\end{array}$ & $\begin{array}{l}1.3 \mathrm{~m} \\
1.703\end{array}$ & $\begin{array}{l}1.5 \mathrm{~m} \\
1.611\end{array}$ & $\begin{array}{l}1.8 \mathrm{~m} \\
1.525\end{array}$ & $\begin{array}{c}2 \mathrm{~m} \\
1.4583\end{array}$ & 0.5 \\
\hline 6 & $\begin{array}{l}\text { Under the } 10 \mathrm{kV}-220 \mathrm{~V} \\
\text { electric aerial cabin of } \\
\text { Telecom, Gjirokastër }\end{array}$ & $\begin{array}{c}1 \mathrm{~m} \\
1.433\end{array}$ & $\begin{array}{l}1.1 \mathrm{~m} \\
1.113\end{array}$ & $\begin{array}{l}1.3 \mathrm{~m} \\
0.836\end{array}$ & $\begin{array}{l}1.5 \mathrm{~m} \\
0.812\end{array}$ & $\begin{array}{c}2 \mathrm{~m} \\
0.735\end{array}$ & 0.5 \\
\hline
\end{tabular}

Figure 1. The measurement of magnetic induction of some sources of non-ionizing radiation in dependence of distance[10,11]. Notes: 1) In measurement 4, the gate of enclosure of the substation is taken as origin of axis; 2) The inaccuracy of the apparatus $\pm 1 \%$ and our inaccuracy in measurement $\pm 0.58 \%- \pm 1.4 \% ; 3$ ) The frequency in all the cases $50 \mathrm{~Hz}$.

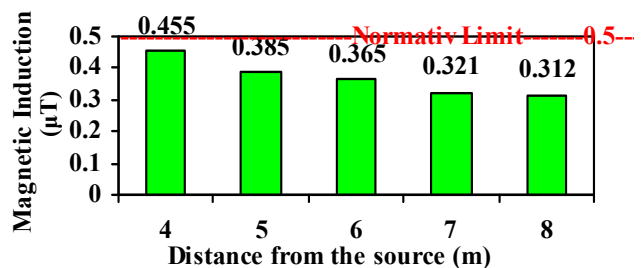

Figure 2. (Measurements of line 3 Figure 1): the influence of distance from the source on radiation. Distance (Under the $6 \mathrm{kV}$ aerial line H/B Delvinë) $[9,10]$.

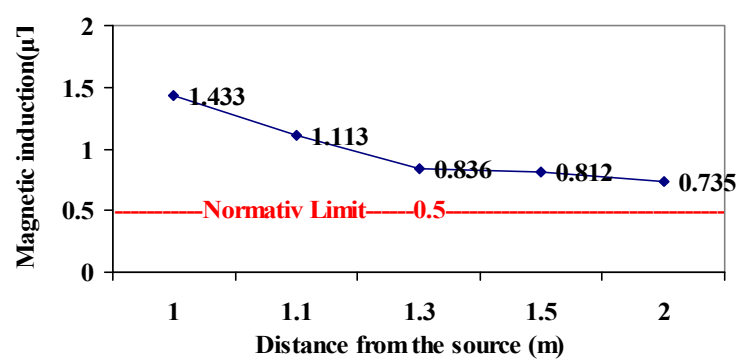

Figure 3. (Measurement of line 6, Figure 1): the influence of distance from source on radiation. ( The $10 \mathrm{kV}-220 \mathrm{kV}$ electric aerial cabin of Telecom, Gjirokastër) $[9,10]$.

sources of non-ionizing radiation depending on distance, (also presented in Figure 1, Figure 2 and Figure 3) showed that, with the increase of distance from the same radiating source, the magnetic induction decreased.

Positively, in the first measurement under the $110 \mathrm{kV}$ electric aerial line of Bistrica H/C, Delvinë, when the distance between the field meter and this line increased to $5 \mathrm{~m}$, the magnetic induction decreased by $0.081 \mu \mathrm{T}$.

In the second measurement under the $10 \mathrm{kV}$ electric aerial line of the Gjirokaster shoe factory, when the distance of the field meter increased to $4 \mathrm{~m}$, the magnetic induction decreased by $0.15 \mu \mathrm{T}$.

In the third measurement under $6 \mathrm{kV}$ electric aerial line of Bistrica, Delvinë, when the distance of the field meter increased to $4 \mathrm{~m}$, the magnetic induction decreased by $0.143 \mu \mathrm{T}$.

In the fourth measurement in the electric substation in Delvinë, when the distance between the field meter and the transformer furthest to the side increased to $4 \mathrm{~m}$, the magnetic induction decreased by $0.271 \mu \mathrm{T}$.

In the fifth measurement on the $10 \mathrm{kV}-220 \mathrm{~V}$ electric transformer in Block of flat Nr.7, "Pllake" Quarter, Gjirokaster, when the distance between the field meter and transformer increased to $1 \mathrm{~m}$, the magnetic induction decreased by $0.375 \mu \mathrm{T}$.

In the sixth measurement under the electrical aerial cabin, where there is a $10 \mathrm{kV}-220 \mathrm{~V}$ transformer of Telecom, Gjirokaster. When the distance between the field meter and the transformer increased to $1 \mathrm{~m}$, the magnetic induction decreased by $0.698 \mu \mathrm{T}$.

In measurement 5 of Figure 1, the radiation level of a $10 \mathrm{kV}-220 \mathrm{~V}$ electric transformer, $1.5 \mathrm{~m}$ away from the dwelling place, is presented. The magnetic induction in the dwelling place is $\mathrm{B}=1.611 \mu \mathrm{T}$. This induction is three times higher than the normative.

In measurement 6 of Figure 1, the radiation level of a $10 \mathrm{kV}-220 \mathrm{~V}$ electric transformer, $1 \mathrm{~m}$ away from a place of 24 hour residence is presented. The magnetic induction in the place is $\mathrm{B}=1.433 \mu \mathrm{T}$. In this case the radiation level was three times higher than the normative too.

Although in measurement 5 of Figure 1 the distance from the source was as big as possible and in measurement 6 of Figure 1 the distance was as small as possible, the situation is as mentioned above.

In this case lack of knowledge and professional abuse are predominant. 


\begin{tabular}{|c|c|c|c|c|c|c|}
\hline \multirow[t]{2}{*}{ No } & \multirow{2}{*}{ Object measured } & \multicolumn{4}{|c|}{$\begin{array}{c}\text { The average of } 6 \text { measurements of magnetic induction } \mathrm{B} \text { (in } \mu \mathrm{T} \text { ) re- } \\
\text { lated to the power of the radiating device (in VA) with distance be- } \\
\text { tween the field measure probe and the source: } 0.2 \mathrm{~m}\end{array}$} & \multirow{2}{*}{$\begin{array}{c}\text { Europe } \\
\text { norm. } \\
\text { of } \\
\text { exposure } \\
\mathrm{B}(\mu \mathrm{T})\end{array}$} \\
\hline & & $\begin{array}{c}\mathrm{P}_{1}= \\
1000 \mathrm{VA}\end{array}$ & $\begin{array}{c}\mathrm{P}_{2}= \\
2000 \mathrm{VA}\end{array}$ & $\begin{array}{c}\mathrm{P}_{3}= \\
5000 \mathrm{VA}\end{array}$ & $\begin{array}{c}\mathrm{P}_{4}= \\
10000 \mathrm{VA}\end{array}$ & \\
\hline 1 & $\begin{array}{c}\text { Stabiliser "Photo Studio Y" in } \\
\text { "18 Shtatori" Quarter, } \\
\text { Gjirokastër }\end{array}$ & - & - & - & $\mathrm{B}_{4}=3.440 \mu \mathrm{T}$ & 0.5 \\
\hline 2 & $\begin{array}{c}\text { Stabiliser "Photo Studio X" } \\
\text { in "18 Shtatori" Quarter, } \\
\text { Gjirokastër }\end{array}$ & - & - & $\begin{array}{c}\mathrm{B}_{3}= \\
1.668 \mu \mathrm{T}\end{array}$ & - & 0.5 \\
\hline 3 & $\begin{array}{l}\text { Stabiliser"Foreign Language } \\
\text { Centre" in "18 Shtatori”" Q., } \\
\text { Gjirokastër }\end{array}$ & - & $\begin{array}{c}\mathrm{B}_{2}= \\
0.691 \mu \mu \mathrm{T}\end{array}$ & - & — & 0.5 \\
\hline 4 & $\begin{array}{l}\text { "Foreign } \\
\text { Language Centre" in"18 } \\
\text { Shtatori"Q., } \\
\text { Gjirokastër }\end{array}$ & $\begin{array}{c}\mathrm{B}_{1}= \\
0.338 \mu \mathrm{T}\end{array}$ & - & - & - & 0.5 \\
\hline
\end{tabular}

Figure 4. Measurement of magnetic induction of some sources of non-ionizing radiation related to the power. Notes: 1) The apparatus inaccuracy $\pm 1 \%$ our inaccuracy in measuring $\pm 0.29 \%- \pm 0.46 \% ; 2$ ) Frequency in all cases $50 \mathrm{~Hz}[9,10]$.

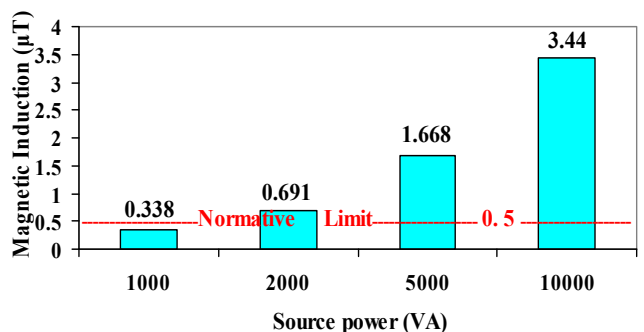

Figure 5. (Measures 1,2,3,4 of figure 4): the influence of the power of the source on radiation (Distance $0.2 \mathrm{~m}$ ) $[9,10]$.

b) The measurements of magnetic induction of some sources of non-ionizing radiation with different powers, of the same type, with a constant measuring distance (to be precise $0.2 \mathrm{~m}$ ), presented in Figure 4 and Figure 5, showed different radiation levels. With the reduction in power the level of radiation decreased as well.

Referring to the measurement 1, 2, 3, 4 of Figure 4 and Figure 5 we notice that:

a) The magnetic induction of an electric stabiliser with 5000 VA power, in Photo Studio "X" "18 Shtatori" Quarter, Gjirokaster, compared to Photo Studio "Y" electric stabiliser of 10000VA, in the same place, is $1.772 \mu \mathrm{T}$ smaller.

$\beta)$ In the Foreign Language Centre a 2000VA electric stabiliser compared to the 10000VA stabiliser of Photo Studio "Y", both in "18 Shtatori" Quarter, Gjirokaster, the magnetic induction is $2.749 \mu \mathrm{T}$ less.

$\gamma)$ Again in the Foreign Language Centre, a 1000VA electric stabiliser compared to the 10000VA electric stabiliser of Photo Studio "Y", in "18 Shtatori" Quarter, Gjirokaster, the magnetic induction is $3.302 \mu \mathrm{T}$ less.

In measure 1 of Figure 4, in Photo Studio "Y", in "18 Shtatori" Quarter, Gjirokaster, it is noticed that a
10000VA stabiliser with induction $B=3.440 \mu \mathrm{T}$ (nearly 6 times of the normative), put there for some device, could be replaced with ten 1000VA stabilisers with induction $\mathrm{B}=0.338 \mu \mathrm{T}$ (under the normative level) or it could be replaced with five $2000 \mathrm{VA}$ stabilisers with $\mathrm{B}=0.691 \mu \mathrm{T}$ (just a little above normal where it could be manoeuvred in distance) or with two 5000VA stabilisers with $\mathrm{B}=1.668 \mu \mathrm{T}$ (nearly 3 times of the normative where also it could be manoeuvred in distance). Although there is the full possibility of minimizing the radiation level, the user of the device hasn't done it. So we are faced with the "cohabitation" of man with non-ionizing radiation above normal levels. In larger areas there are devices of high power close to inhabited places as well as devices with unjustified power in small areas.

c) The measurement of magnetic induction of both sources of the same type, with different frequencies, for the same measuring conditions in general and the same measuring distance in particular (actually $150 \mathrm{~m}$ ), displayed in Figure 6 and Figure 7, show they have different radiation levels. They show that, the smaller the frequency, the smaller the radiation level is.

Between the second measurement of Figure 6, Figure 7 , made in the mobile phone antenna, put on top of " $\mathrm{X}$ " Hotel in 18 Shtatori Gjirokaster, with a frequency $900 \mathrm{MHz}$ and the first measurement on top of "Y" hill, in Gjirokaster, with a frequency of $1800 \mathrm{MHz}$, the difference of the non-ionizing radiation level is $0.276 \mu \mathrm{T}$. So, in the first case it was $0.276 \mu \mathrm{T}$ less.

\section{CONCLUSIONS}

For the three types of the above measurements we can draw the corresponding conclusions:

1) When the exposed object from the non-ionizing 


\begin{tabular}{|c|c|c|c|c|c|}
\hline \multirow[t]{2}{*}{ No. } & \multirow[t]{2}{*}{$\begin{array}{l}\text { Location where measure- } \\
\text { ment took place }\end{array}$} & \multicolumn{2}{|c|}{$\begin{array}{l}\text { Average of } 6 \text { measurements } \mathrm{B} \text { (in } \mu \mathrm{T}) \\
\text { of both antennas with the same distance } \\
\text { from the field measure }(150 \mathrm{~m}) \text {. Different } \\
\text { frequencies of antennas. }\end{array}$} & \multirow[t]{2}{*}{$\begin{array}{c}\text { European normal } \\
\text { of exposure } \\
\mathrm{B}(\mu \mathrm{T})\end{array}$} & \multirow[t]{2}{*}{ Observation } \\
\hline & & $1800 \mathrm{MHz}$ & $900 \mathrm{MHz}$ & & \\
\hline 1 & $\begin{array}{c}\text { Mobile Phone Antenna on } \\
\text { top of Hotel }(\mathrm{X}) \text { in "18 } \\
\text { Shtatori" Quarter, Gjiro- } \\
\text { kastër }\end{array}$ & - & $0.059 \mu \mathrm{T}$ & 0.3 & Below normal \\
\hline 2 & $\begin{array}{l}\text { Mobile Phone Antenna on } \\
\text { Hill (Y) in Gjirokastër }\end{array}$ & $0.335 \mu \mathrm{T}$ & - & 0.4242 & Below normal \\
\hline
\end{tabular}

Figure 6. Table of magnetic induction measurement of two sources of the same kind with different frequencies at the same measuring distance. Note: 1) Apparatus inaccuracy $\pm 1 \%$ and our inaccuracy in measuring $\pm 0.51 \%- \pm 0.8 \%$; 2 ) Frequency in all cases $50 \mathrm{~Hz}$.

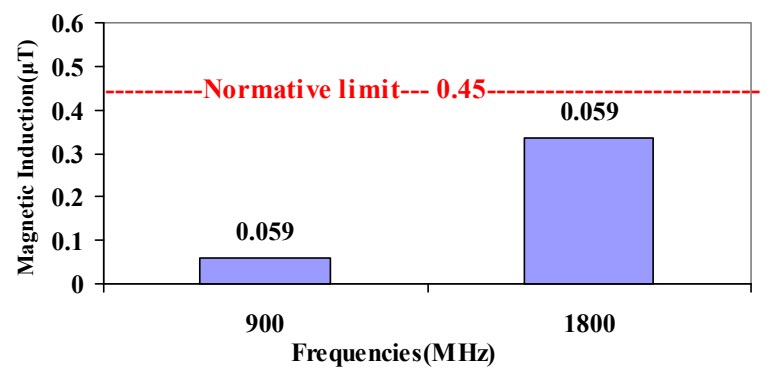

Figure 7. (Measurement of line 1\&2 of Figure 6): the influence of the frequency of the source on radiation.

source is mobile, its positioning should be at that distance from the source which corresponds to the normative radiation level. When it is absolutely fixed, the source should be relocated.

2) The selection of radiating sources should be done according to the necessary power. Devices with highpower may not be relocated if unnecessary. When a high power device is necessary and space of the living or working area doesn't allow to have them far away, their power should be compensated by a low power non-ionizing radiation source, as their radiation level is smaller. It is very important to distribute the compensating sources so that we don't have a superposition of waves. Distribution should be done with a field measure, so that the radiation level corresponds to the international standards. Even when the radiation level is normal, the exposure time in this case should also be according to international standards.

The measurements 'recommend' the replacement of high frequency antenna with antenna of low frequency, according to the compensation method. Attention should be paid to avoid a superposition of their waves. A superposition of waves might be caused by other large antennas from unknown sources. Such superposition may cause above normative radiation, which should definitely be avoided. The specialised and authorised state organ should monitor periodically the state of af- fairs and seek strict respect to the restrictive normatives of ICNIRP with a special legislation.

\section{REFERENCES}

[1] Griffiths, D.J. (2007) Introduction to electrodynamics. 2nd Edition, Prentice-Hall, England, 1989-1996.

[2] Krane, K. (1996) Modern physics. 2nd Edition, Department of Physics, Oregon University, USA.

[3] Varocos, P. and Aleksandropullos, K. (1995) Physics of the rigid body. Publishing house Savalla, Athens.

[4] Mejdani, R. (1997) The Theoretical-conceptual bases of physics. Publishing House of University Books, Tiranë.

[5] Klosi, F., Treska, M. and Prifti, I. (1990) General physics 4-waves. Publishing House of University Books, Tiranë.

[6] Bilero, V.T. and Kote, M. (2008) The classification of non-ionizing radiation scources and the comparison of measured radiation of some sources of this kind with the international normatives. The Polytechnic University, Tiranë.

[7] Margaritis, H.L. and Panagopullos, I.D. Biological Effects of non-ionizing radiation. University of Athens, Athens, http://kyttariki.biol.uoa.gr.

[8] Non-ionizing radiation. (2004). www.physics4.gr/faq/ radiationcells1.html.

[9] Ksanthi, P. and Konstandina, A.N. (2004) Application of computer techniques for the study of mobile phones and the base systems of this phone. Polytechnic University, Athens. artemis.cslab.ntua.gr/el thesis/search.pl?handle $=$ DT20040135.

[10] ICNIRP. 2009 "International Commission for Non-Ionising Radiation Protection" www.mobile-phonedirectory.org/Glossary/I/ICNIRP.html.

[11] Official Journal of European Union L 159. Directive 2004/40/EC of the European Parliament and of the council, 29 April 2004. "Exposure limit and action values for electromagnetic fields", Page 21-24 http://eurlex.europa.eu/LexUriServ/LexUriServ.do?uri=O J:L:2004:159: 0001:0026:EN:PDF.

[12] The non-ionizing radiation of mobile phone antennas. File:///radiationcells $1 . \mathrm{html}$. [13] Non ionizing radiation.
en.wikipedia.org/wiki/Non-ionizing_radiation. 